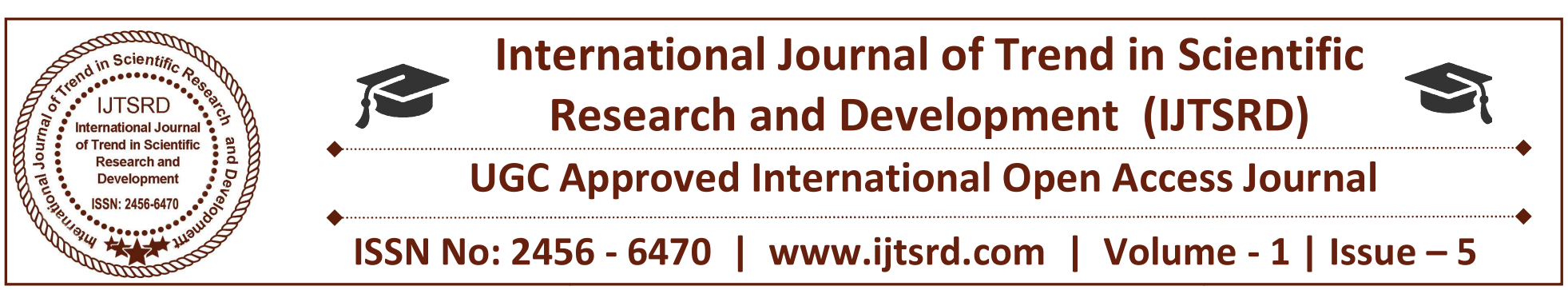

\title{
Solar Power Tree - An Artistic Design
}

\section{Mohd Nissar}

Department of Electrical and Electronics Engineering (EEE), Al- Falah University, Faridabad, India

\author{
Dr. Aziz Ahmad \\ Department of Electrical and Electronics Engineering \\ (EEE), Al- Falah University, Faridabad, India
}

\begin{abstract}
If the $19^{\text {th }}$ century was the age of coal and the $20^{\text {th }}$ century of oil, the $21^{\text {st }}$ will be the age of sun (Solar Energy). The demand of energy is increasing with each period, with the result that the prices increasing day by day. For example, with the supply of oil the quantity of oil is decreasing and the prices are increasing. Similarly in case of coal which is abundantly for the production of electricity is available for few more hundred years. Nuclear energy produces abundant power but many fear that repercussion of catastrophes such as Chernobyl. So in order to fulfil the increasing demand we must concentrate on utilising the non-conventional sources of energy. Energy from the sun is the best alternative among all the renewable sources. It is free, Inexhaustible, non-polluting, eco-friendly and continuous source of energy. The main drawback of solar panels is the land requirement for the installation of solar panels. But in solar tree we use very less land to produce large amount of electrical power.
\end{abstract}

\section{INTRODUCTION}

Non-conventional energy resources which are being produced continuously in nature and are inexhaustible are called renewable sources of energy. There are various sources which are used to produce the electric power generation such as solar energy, Wind energy, Tidal energy, Ocean thermal energy, geothermal energy etc, but solar energy is the best alternative among all the alternatives of non-renewable energy resources.

A solar tree is similar to that of a natural tree but the solar tree is the artificial tree in which photo-voltaic cells or modules are arranged in a Fibonacci series pattern instead of leaves. In 1209 in Pisa, Leonardo of Pisano, also known as "Fibonacci" used his skill to answer a math puzzle about how fast rabbits could reproduce in pairs over a period of time while counting his new born rabbits; Fibonacci came up with a numerical sequence. Fibonacci use this pattern in ancient Sanskrit poetry from India to make a sequence of numbers starting with zero (0) and one (1). Fibonacci added the last two numbers in the series together, and the sum became the next number in the sequence. The number sequence started to look like this $1,1,2,3,5,8,13,21,34 \ldots \ldots \ldots .$. The number pattern had the formula $\mathrm{F}_{\mathrm{n}}=\mathrm{F}_{\mathrm{n}-1}+\mathrm{F}_{\mathrm{n}-2}$ and became the Fibonacci sequence.

The solar tree produces more energy than a conventional flat plate arrangement of solar panels or modules. The solar energy conversion is the conversion of sunlight energy into electrical energy making use of sunlight directly by using the photovoltaic or concentrated solar power. The photoVoltaic effect is defined as the generation of electromotive force as a result of absorption of ionising radiation energy conversion devices which are used to convert sunlight to electricity by the use of photo-voltaic effects are called solar cells.

A single converting cell or more generally a photo voltaic cell, but a combination of cells whether in series or parallel designed to increase the power output is called solar module or solar array. PhotoVoltaic cells are made up of semiconductors that generate electricity when they absorb light. As the photons are incident on the semi-conductor free 
electrical charges are generated that can be collected on the contacts of the surface of the semi-conductor.

\section{DESIGN OF SOLAR POWER TREE}

It is a combination of artistic and technological efforts which exists as a frame of artwork. As we already know that the angles of the sun rays are not fixed particularly when the season changes then the flat plate roof tops are inefficient because they cannot trap the maximum sunlight (solar rays) as they are fixed. Some solar system based residential are designed with the maximum power tracking system, that means that the solar system or the solar panels are incorporated with such a moving system that will rotate with respect to the sun or in other words we can say that it should have to be rotated from east to west facing its panels towards south (India) after specific intervals of time, which in turn increases the cost of the solar system and also require a greater maintenance. So we designed a solar power tree ( With the help of Google sketchup - A 3D Software ) using arrays of solar panels instead of leaves in the natural trees. Solar power tree or solar photo-voltaic trees are the solar structures looking like as that of real natural trees. These trees can be framed from a small scale like bansoi tree to a large scale like a wind turbine. This is relatively a new idea which is conceived to use new technologies relating to use and harvest the solar energy. The panels are arranged in a tree in a tall steel pole.

\section{Tree Represents}

$$
\begin{aligned}
& \mathrm{T}=\text { Tree Generating } \\
& \mathrm{R}=\text { Renewable } \\
& \mathrm{E}=\text { Energy and } \\
& \mathrm{EL}=\text { Electricity }
\end{aligned}
$$

We planned to design the stems (Rectangular/Circular) of the tree steel pipes which support the panels. Then these panels are connected to the inverter by the charge controller through the wires and the power is fed to the electric grid. Also we can install batteries which are hidden inside the ground base to store the electric energy and the battery is closed with proper material from protection of mechanical damage and also from chemical effects like corrosion etc. To trap maximum power from the sun, Spiralling Phyllotaxy (arrangement of leaves on stem) technique is used i.e. the panels are arrange like a manner of like that of spring which is found in the trees, that means this technique will help the lower panels from the shadow of the upper ones and also the face of the panels must be towards the direction of the sun. The components of the solar tree are

\section{Solar panels \\ Long Tower \\ $>$ Inverter \\ $>$ Batteries \\ $>$ Stems for connecting the panels ( Circular and Rectangular) \\ $>$ Wires, Bushes, Nut Bolts etc.}

$>$ LEDs

\section{SOLAR POWER TREE WORKING}

Solar tree is designed to function both autonomously and with the synchronization with the public grid. Electric grid, it uses the energy generated by the solar panels during the to recharge the batteries or the power generated by the pannels which is in the form of DC is converted into ac with the help of inverter and it is fed to the synchronized public grid. At dusk, which is recognised by automatically monitering the solar panel output, the LED sources are activated and remain lit until dawn ( As long as the batteries remain charged). Solar tree is capable of functioning for three consective days of cloudy or overcast weather. When wired for co-ordinated functioning with the public lightening grid, it uses the energy generated by the solar pannel to recharge the batteries or the power is fed to the public grid through the inverter and activate / deactivate LEDs sources in synchronous with the grid, to which the surplus of stored current can be relinquished. Number of solar pannels are used to give the shape of a tree and arranged in a tall steel tower/ pole. The total number of pannels installed will depend on the power output which is the desired output power we need to produce. And according to that we have to connect the panels in series or paraallel.

Major problems of the power system are the storage of electric energy. Solar tree panels generate power during the day time and this power is supplied to the grid during the day or it can be stored in the batteries but it is preferable to fed the generated power to the grid and if the LEDs are installed or load is connected then the solar tree automatically switches on its LEDs/ Load. A sensor is used to measure the amont of light in atmosphere and triggers the solar panels to switch "ON" automatically at sunset and "OFF" at sunrise. 


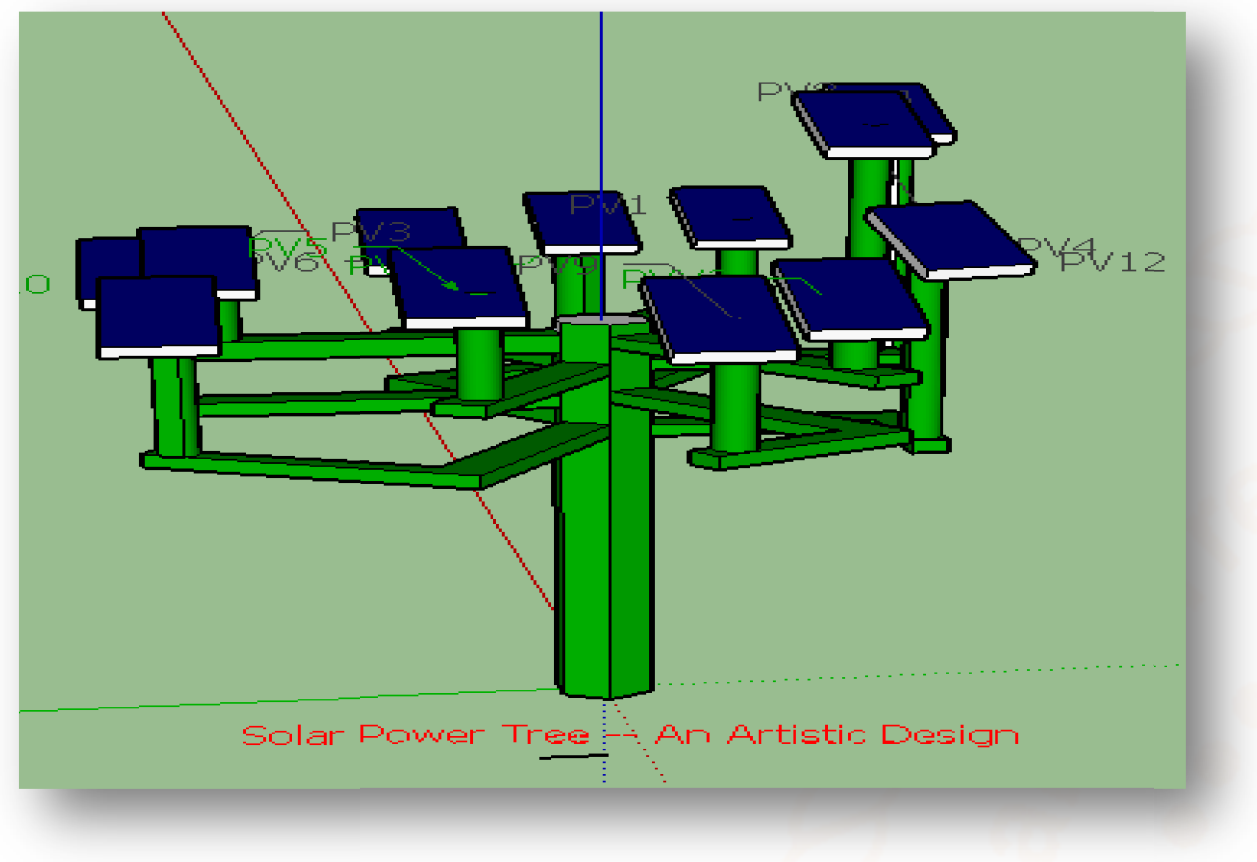

Fig. 1 Solar Power Tree - an artistic Design

\section{ORIENTATION GIVEN TO PANNEL}

\section{Load Estimation:-}

\begin{tabular}{|c|c|c|c|c|c|}
\hline Appliance & Number & Power & Daily Use & $\begin{array}{c}\text { Hourly } \\
\text { Distribution }\end{array}$ & $\begin{array}{c}\text { Daily } \\
\text { Energy }\end{array}$ \\
\hline Lamps ( LED or fluoresent) & 10 & $7 \mathrm{~W} /$ lamp & $10 \mathrm{~h} / \mathrm{Day}$ & Ok & $280 \mathrm{wh}$ \\
\hline TV/PC/Mobile & 2 & $100 \mathrm{~W} / \mathrm{App}$ & $3 \mathrm{~h} / \mathrm{Day}$ & Ok & $600 \mathrm{Wh}$ \\
\hline Domestic appliances & 1 & $200 \mathrm{~W} / \mathrm{App}$ & $3 \mathrm{~h} / \mathrm{Day}$ & Ok & $600 \mathrm{Wh}$ \\
\hline Fridge / Deep-freeze & 0 & 00 & 00 & & 00 \\
\hline Dish and Cloth wash & 0 & 00 & 00 & & 00 \\
\hline Others use & 2 & $100 \mathrm{~W} / \mathrm{App}$ & $3 \mathrm{~h} / \mathrm{Day}$ & Ok & $600 \mathrm{Wh}$ \\
\hline Other use & 2 & $50 \mathrm{~W} / \mathrm{App}$ & $2 \mathrm{~h} / \mathrm{Day}$ & Ok & $200 \mathrm{Wh}$ \\
\hline Standby consumer & & $6 \mathrm{~W}$ tot. & $24 \mathrm{~h} / \mathrm{Day}$ & & $144 \mathrm{Wh}$ \\
\hline
\end{tabular}

Total daily energy $=2424 \mathrm{Wh} /$ Day

Total monthly energy $=72.7 \mathrm{Kwh} /$ month 
Definition of Daily Household consumptions for Summer (Jun-Aug)

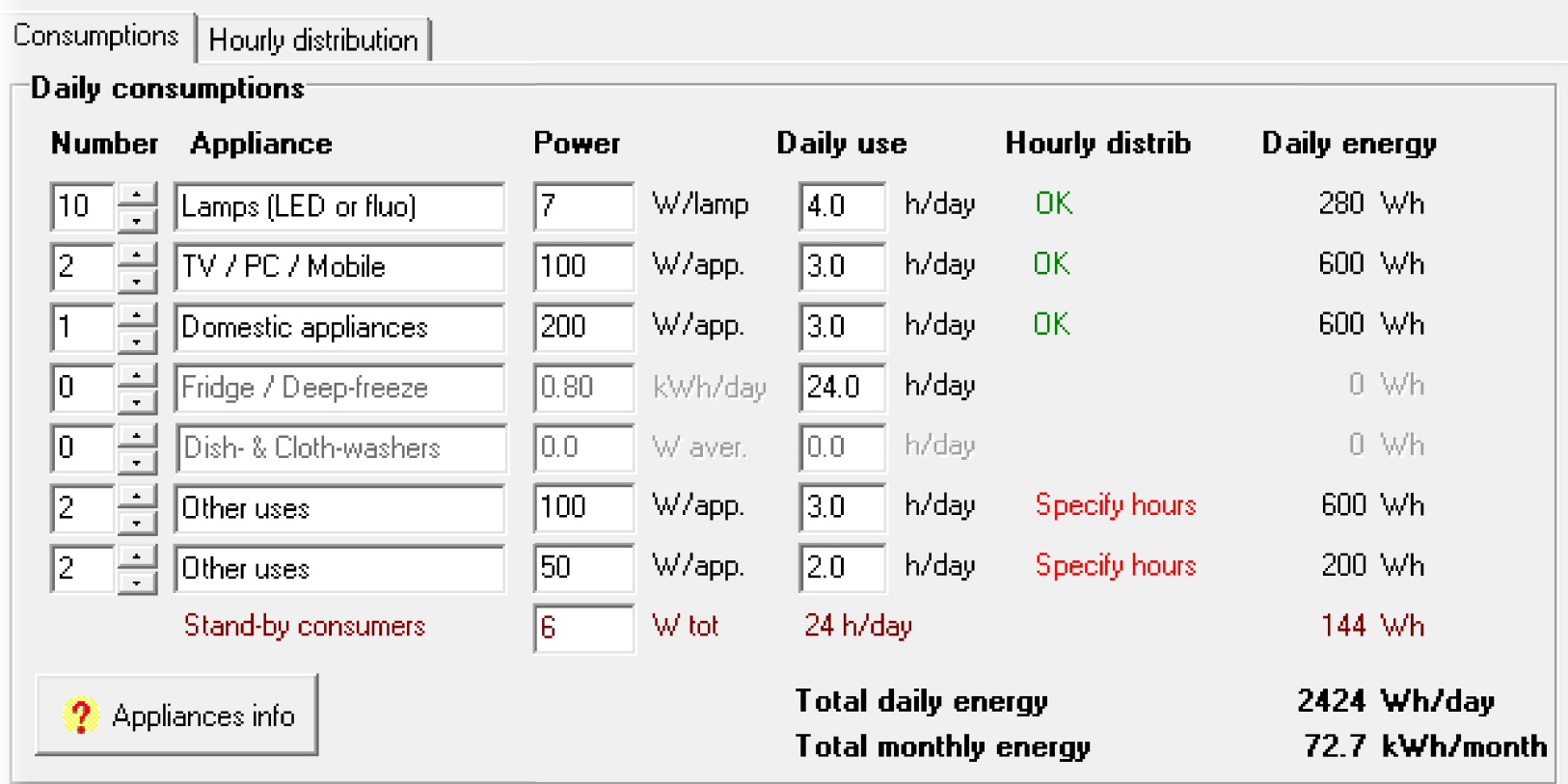
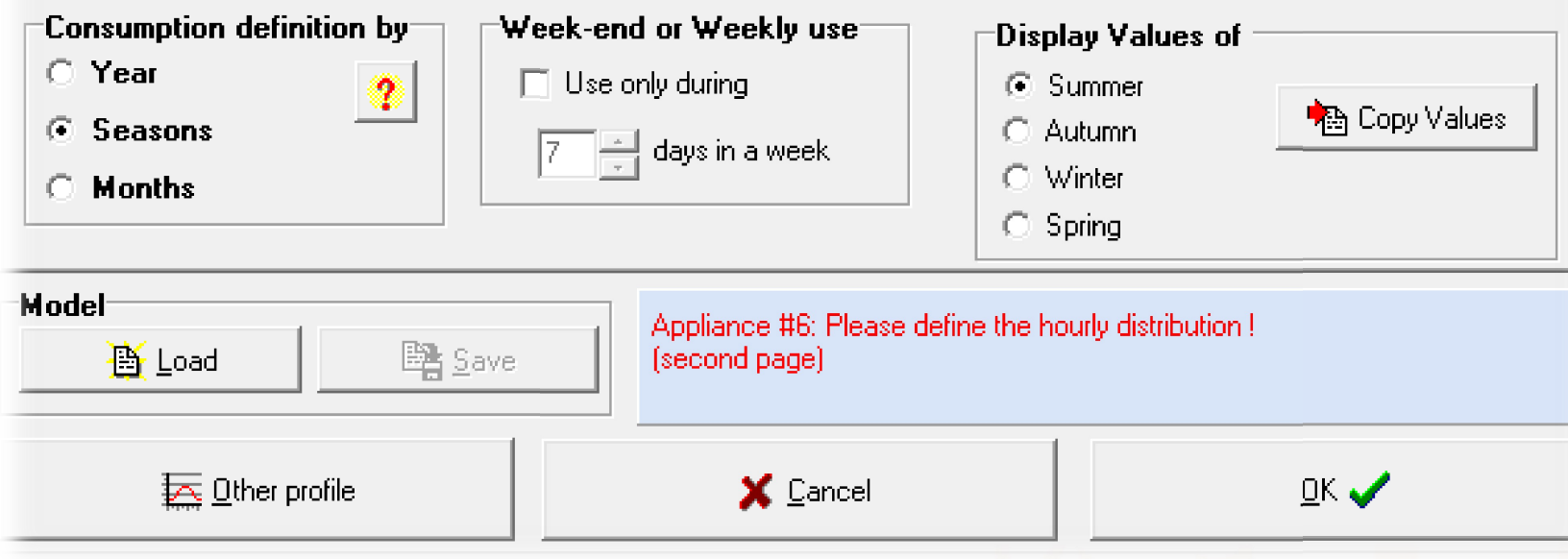

Appliance \#6: Please define the hourly distribution!

[second page]

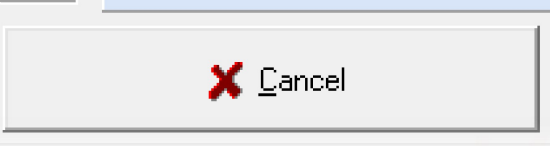

마

Fig. 2 Load Estimation

\section{Selection of system voltage:-}

Based on the rquirement of the system, voltage is selected and as we have a load demand less than $5 \mathrm{kw}$, therefore the system voltage is selected as $24 \mathrm{~V}$ dc.

\section{Determinition of PV array size:-}

The size of the PV array can be selected on the efficiency of inverter / controller suppose $90 \%$ and battery bank and wire loss $3 \%$. The energy requirement for the PV array size is

$$
\begin{aligned}
& =\frac{1}{\eta_{\text {batte }} \times \eta_{\text {Charge controller }} \times \eta_{\text {Wiring }}}=\frac{1}{0.9 \times 0.9 \times 0.97} \\
& =\frac{1}{0.7857}=1.2727
\end{aligned}
$$


Hence the needed from the module (PV array)

$\mathrm{P}_{\text {array }}=\mathrm{E}_{\mathrm{a}} \times 1.2727$

Where $E_{a}$ is the average daily energy consumption in wh/Day

Hence $\quad \mathrm{P}_{\text {array }}=2424 \times 1.2727$

$$
=3085.0248 \mathrm{~W}
$$

\section{Total Array Current:-}

The total module current $\mathrm{I}_{\mathrm{dc}}$ is calculated by dividing the above paek watt rating by the system voltage $V_{d c}$

$$
\mathrm{I}_{\mathrm{dc}}=\frac{\mathrm{Wpe}}{\mathrm{Vdc}}
$$

Here $\mathrm{W}_{\text {peak }}=\frac{3085}{6} \quad=514 \mathrm{~W}_{\mathrm{p}}$

Therefore $\mathrm{I}_{\mathrm{dc}}=\frac{514}{24}=21.42$ Amp.

As we have selected solar module manufactured by Vikram solar India. The specification of the modules are as follows

\begin{tabular}{|l|l|}
\hline Peak Power $\mathbf{P}_{\max }(\mathbf{W p})$ & 300 \\
\hline Maximum voltage $\mathbf{V}_{\text {mpp }}$ (V) & 37.05 \\
\hline Maximum Current $\mathbf{I}_{\text {mpp }}$ (I) & 8.10 \\
\hline Open Circuit Voltage $\mathbf{V}_{\text {oc }}$ (V) & 45.58 \\
\hline Short Circuit AC current $\mathbf{I}_{\text {sc }}(\mathbf{A})$ & 8.58 \\
\hline Module Efficiency (\%) & 15.63 \\
\hline
\end{tabular}

\section{Inverter Size:-}

Inverter Rating $=3 \mathrm{KVA}$

\section{Specifications}

\subsection{Input}
a. PV Voltage ( Charging Voltage ) (Voc)
$=$
b. PV current
(I)
c. Battery voltage
$\mathrm{Vdc}$
$=\quad 50 \mathrm{~A}$
$=\quad 48 \mathrm{~V}($ Nominal $)$

\subsection{Output}

a. Output voltage (AC) of the inverter

b. Frequency of the output

1.3. Capacity of the inverter

\section{Total Number of panels required:-}

As we calculated above that the total energy required from the solar panels is 3085 i.e about $3 \mathrm{kw}$. And also we are using the PV panels of 300-350wp. So we have to install 10 panels on the solar power tree. Therefore number of panels required $=10$

\section{Battery Bank Size:-}

The total DC Load requirement $=\frac{\mathrm{P}_{\text {array }}}{\text { system voltage }}$

$$
\begin{aligned}
& =\frac{3085}{24} \mathrm{Ah} \\
& =128.54 \mathrm{Ah}
\end{aligned}
$$

Considering battery autonomy for two days total requirement $=2 \times 128.54 \mathrm{Ah}$

$$
=257.08 \mathrm{Ah}
$$

Considering the battery efficiency and Depth of Discharge (DOD) equal to $80 \%$

Battery capacity $=401.6875 \mathrm{Ah}$ 
Charge controller capacity:-

The standard plasticising the size of charge controller is to ensure that it can withstand the product of the total current of the array Isc $\mathrm{A}=\mathrm{IscM} \times \mathrm{Nmp}$ and a certain fuse factor (Fsafe)

Therefore Icc $=$ Isc $\times \mathrm{Nmp} \times$ Fsafe $=41 \mathrm{~A}$

\section{Results Obtained from seizing of the proposed Solar Power tree}

\begin{tabular}{|c|c|c|}
\hline Component & Description of Component & Capacity \\
\hline Load Estimation & Total Estimated Load & $2424 W$ \\
\hline \multirow[t]{4}{*}{ PV Array } & Capacity of PV Array & $514 \mathrm{Wp}$ \\
\hline & Number of modules in series & 2 \\
\hline & Number of Modules in parallel & 5 \\
\hline & Total number of modules & 10 \\
\hline \multirow[t]{4}{*}{ Batteries } & Battery bank capacity & $401.6875 \mathrm{Ah}$ \\
\hline & Number of batteries in series & 4 \\
\hline & Number of batteries in parallel & 0 \\
\hline & Total number of batteries & 4 \\
\hline \multirow[t]{2}{*}{ Charge controller / Voltage regulator } & $\begin{array}{l}\text { Capacity of Voltage regulator / } \\
\text { Charge controller }\end{array}$ & $41 \mathrm{~A}$ \\
\hline & Number of regulators required & 1 \\
\hline Inverter & Capacity of inverter & $3 \mathrm{KVA}$ \\
\hline \multirow[t]{2}{*}{ Wires } & $\begin{array}{l}\text { The DC cable from the PV array to } \\
\text { the battery bank through the charge } \\
\text { controller }\end{array}$ & $16 \mathrm{~mm} 2$ \\
\hline & $\begin{array}{l}\text { The } \mathrm{AC} \text { cable from the inverter to the } \\
\text { distribution board(DB) of the } \\
\text { residence }\end{array}$ & $4 \mathrm{~mm} 2$ \\
\hline
\end{tabular}

\section{Cost Estimation of the System:-}

\begin{tabular}{|l|l|l|l|l|}
\hline Component & Model Quantity & $\begin{array}{l}\text { Unit Cost } \\
\text { (Rs) }\end{array}$ & $\begin{array}{l}\text { Cost per } \\
\text { component } \\
\text { ( Total) }\end{array}$ \\
\hline PV Modules & Vikram Solar ELDORA & 10 & 9000 & 90,000 \\
\hline Batteries & EXIDE & 4 & 8000 & 32000 \\
\hline Voltage Regulator & $\begin{array}{l}\text { SU-KAM SOLAR CHARGE } \\
\text { CONTROLLER }\end{array}$ & 2000 & 2000 \\
\hline Inverter & $\begin{array}{l}\text { CUSTOM BUILT 3KW 48V DC } \\
\text { TO 220/230V AC PURE SINE } \\
\text { WAVE POWER }\end{array}$ & 8000 & 8000 \\
\hline $\begin{array}{l}\text { Fabrication cost of the solar power tree } \\
\text { Metal Bars ( Circular ), Metal Bars ( Rectangular ), Metal Strips, Nut Bolts, } \\
\text { Rubber Bush, Plastic Box, Wires, Fuse }\end{array}$ & 2500 \\
\hline
\end{tabular}

Total Cost of the system $(\mathrm{Rs})=1,34,500$ 


\section{CONCLUSION:-}

If the $19^{\text {th }}$ century was the age of coal and the $20^{\text {th }}$ century of oil, the $21^{\text {st }}$ will be the age of sun (Solar Energy). In the world oil is running out and it is estimated that $80 \%$ of the world supply will be consumed at our lifetimes. Coal supplies appear to be very large but this stock will be vanished if rapidly uses. Therefore the Solar power tree is very efficient to capture large amount of solar energy by utilizing a very small surface area of valuable land. They can be installed on road side as they consume 4 sq. Feet area for a single tree. The village roads and the boundary walls of the paddy fields can provide sufficient space for planting solar power trees that can supply enough power for electrification of villages and irrigation activities. The State and National Highways are the big source of planting solar power trees. A simple calculation shows that if a National Highway having length of $300 \mathrm{Km}$ is installed with solar power trees, it would produce $110 \mathrm{MW}$ of power.

\section{REFERENCES:-}

1) Dr. Suwarna Targol “ Concept of Solar Power Tree" International Advanced Research Journal in Science, Engineering and Technology, Vol. 3,issue: 4, April 2016

2) C. Bhuvaneswari, R. Rajeshwari, C. Kalaiarasan, K. M. S. Muthukumararajaguru "Idea to Design a Solar Tree Using Nanowire Solar cells" International Journal of Scientific and Research Publications, Volume 3, issue 12 ISSN: 22503153 ,

December

2013

3) Sushma Gupta, Monish Gupta “ The Benefits and Applications of Solar Tree with Natural Beauty of Trees" SSRG International Journal of Electrical and Electronics Engineering (SSRG- IJEEE), ISSN:- 2348-8379 April 2015

4) Rohini Jadhao "Solar Power Tree" International Conference on Emanations in Modern Technology and Engineering, (ICEMTE-2017), Volume: 5, Issue: 3, ISSN: 2321-8169, 2017

5) Kriti Vibhute, Ramakant Shukla, " Economic Electrification Using Solar Tree" International Journal of Science, Engineering and Technology Research (IJSETR), Volume 4, Issue 6, ISSN: 2278-7798, June 2015
6) R. Sankar, P. K. Jery Althaf,and S. Sreevas "A Study on Low Cost Electrification Using Solar Energy a Field Work" International Journal of Computer Theory and Engineering, vol. 4, No. 6 December 2012

7) S. N. Maity "Development of Solar Power Tree An Innovation that Uses Up Very Less Land and Yet Generates much more Energy From the Sun Rays by SPV method" Journal of Environment Nanotechnology vol. 2 (2013) 59-69 pp. ISSN (Print) : 2279-074, ISSN (Online) : 2319-5541

8) Rachit S*, Vinod KG "Solar Power- Current Status, Challenges and Polices in India" Research and reviews: Journal of Engineering and Technology 